\title{
ACEHNESE WOMEN STRUGGLE FOR PEACE AND JUSTICE: CHALLENGES AND OPPORTUNITIES
}

\author{
Asna Husin*
}

\begin{abstract}
We explore the concept of peace from a broader sense than merely the absence of war, through the eyes of Acehnese women who continue to strive for better political representation and social justice utilising Islam as their foundational point. The study analyses Islamic principles of peace, cultural beliefs and practices, as well as the political environment, which engulfed Aceh. Historical accounts and academic research form a theoretical base for our analysis, while interviews with influential women, Ulama leaders, political figures as well as community activists provide integral content for our survey. This inquiry concludes that in spite of widespread political conservatism being promoted by the GAM political party of Partai Aceh and parochial religious fanaticism being advocated by certain transnational groupings, women themselves provide hope for gender equality and empowerment. Women of the dayah (Islamic boarding school) and NGO activists may work together to pursue their Islamic endowment of peace and accomplish pragmatic actualisation of equality and justice.
\end{abstract}

\section{Introduction}

Gender is regarded by many as a secular value infiltrated into Acehnese and other Muslim societies through Western influence. Though there is some truth in this perception, especially with the use of the terms 'gender equality' or 'human rights' for women and the discursive debates employed in promoting them, Muslim women's efforts for representation and arguments for equity are as old as Islam itself. Umm Salamah, the wife of the Prophet Muhammad, once asked him: "What is with us (women) that we are not mentioned [by God] in the Qur'ān as men are mentioned?" God heard her complaint and then the verse ${ }^{1}$ (Q al-Ahzāb 33:35): "Surely the Muslim men and women and the faithful men and women..." was revealed. ${ }^{2}$ Similarly, Arwah or Umm Mūsa, wife of the second "Abbasid Caliph al-Manșūr, requested a written marriage stipulation from her husband that he would neither marry a second wife nor take a concubine while she was still alive. ${ }^{3}$ When the Caliph subsequently regretted his agreement and sought it annulled, Arwah appealed to the chief justice whose verdict ruled in her favour.

Both Umm Salamah's advocacy for equal treatment of men and women in Allah's revelation, and Arwah's attempt to not share her husband with other women, were gender-oriented advances advocating women's rights and equity. These examples demonstrate that while these two great ladies of Islam may never 
have recognised the term gender nor promoted explicit gender discourse, yet gender was acted upon as second nature to them. Understanding gender as an act rather than a discursive idea is very important in our discussion of women's rights and responsibilities in an Islamic context, for this same attitude is being repeated in Aceh and was found in many other Islamic societies throughout history.

This paper explores women's active participation in public life in Indonesia's westernmost province of Aceh, as a form of peacemaking in which women mediate paths to active peace in their community providing a sense of orientation and objective in the activities of their family and society. We begin with a brief survey of the role of Islam in women's understanding of peace, their search for individual and collective rights as well as for public responsibilities. Then we focus on the challenges facing women within the constraints of a traditional Islamic society such as Aceh, as they evolve toward their own specific form of modernity, highlighting their religious and cultural possibilities and limits in their engagement. The last section explores the new reality that may fuel the further advancement of women or hinder them in moving forward, recognising the essential contribution of female religious authorities in their work to educate youth and to uplift their society, as well as those conservative political elements which manipulate religious aspirations and seek to mitigate peace building efforts.

\section{Islam and Acehnese Women's Participation in Public Life}

The name Islam, or the Arabic term "al-isläm", derives from the notion of salm, silm, and salammah meaning security, peace-making, resignation and conciliation, and is also associated with the term saläm 'salutations of peace \& security'. Sincere resignation to Allah's revealed guidance is the essential connotation of the word "isläm," and as a conventional technical term it serves as the name for the Muslim faith: "I have chosen Islam as your religion" (Q al-Mā'idah 5: 3). ${ }^{4}$ Another important spiritual foundation for peace in Islam is the belief that God is the ultimate source of Peace: "He is God; there is no god save He; the King; the Holy and the Peace [al-Saläm]" (Q al-Hashr 59: 23). The notion of God being named al-Salām is repeated in the supplication $\left(d u^{\prime} \bar{a}^{\prime}\right)$ recited by Muslims at the conclusion of the five daily obligatory prayers (salät): "O God, You are Peace, the Source of Peace, and to You Peace returns ..." This understanding that God is the origin of Peace is traditionally attributed to Khadijah, the beloved first wife of the Prophet, when she responded to "the salutations of peace from [her] Lord" by saying: "Allāhu l-Salām wa minhu l-Salām [God is Peace and from Him Peace derives]." ${ }^{5}$ The Qur'ānic testimony and Khadījah's recognition of God being alSalām, as well as the divine naming of the Muslim faith al-islām, highlight that 
peace is an intrinsic part of Islam. Therefore, peace from an Islamic perspective embodies both a vertical spiritual dimension as well as horizontal practical aspects, for God al-Salām reveals al-islām as a religion enjoining human beings to experience lives of peace and security in the best sense of the word.

Peaceable living in the real sense of the word is reflected in the notion that peace in Islam is neither merely the absence of war nor the elimination of discrimination and injustice in the community. It is holistic peace implanted in the essence of the human constitution (fitrah - innate recognition of monotheist reality) radiated into their hearts as a manifestation of their sincere resignation to God al-Salām as true Source of Peace, and translated into healthy thinking and positive attitudes extended to peaceful treatment of fellow men and women, as well as the flora and fauna or their natural surroundings. Such a comprehensive approach to peace is a fundamental principle in the Muslim activation of peace and security throughout ages. However, the complexity of Muslim cultural life and recent history, the nature of relations within their own communities and with their fellow humans and other nations, and the level of Muslim spiritual and intellectual astuteness as well as their collective political stability, has led many Muslims to overemphasise one dimension of Islamic teachings at the expense of other aspects. When it comes to the issue of the role of women, cultural dimensions guided by intellectual discrepancies now clenching Muslim communities worldwide often overrule the spiritual inclusiveness and foundational openness of Islam. These challenges actually provide women either an opportunity to engage in social activities and peace building, or pose an obstacle preventing their progress. Deciphering the situation from the reality of contemporary cultural constraints: women may be both victims of societal incompetency as well as advocates for communal advancement.

Women in Aceh, like many other areas in Indonesia and South East Asian nations, have historically lived in a women-friendly environment. The form of Islam, which penetrated Aceh from the ninth to twelfth centuries CE by means of traders and Sufi fraternities, contributed to and encouraged the free movement and social engagement of women. Commonly engaged in the market place and within Sufi groupings, women were as active as men in commerce and the tarīqah. In the political arena Acehnese have romanticised their experience of women leaders, especially the famous four Sultanahs who ruled over Aceh for fifty-nine consecutive years (1641-1699), and the woman admiral Keumala Hayati who controlled the Sultanate's sea security, as well as female revolutionary leaders fighting the Dutch colonials. ${ }^{6}$ The women leaders of traditional Islamic learning institutions called dayah (from Arabic zäwiyah 'study lodge') were also celebrated. However, prolonged conflicts during Suharto's decentralisation and unification policy (1967-1997) limited women's active role as religious preachers 
(penceramah) and as community leaders, which had been common phenomena up to 1970 s.

While traditional religious openness enabling the public role of women evaporated, a new kind of women social activism emerged. Conflict, violence and political limitations (to evoke Michel Foucault's 'docile body') brought a new energy to the people of Aceh. Many students and young men and women reacted to their political limitations by establishing new non-governmental organisations (NGOs), and this fresh civic energy mushroomed in Aceh and all over Indonesia. This was made possible as Indonesia opened up during the peaceful political and social revolution of reformasi in the late 1990s that led to the fall of Suharto, and encouraged political openness and democracy. ${ }^{7}$ Sympathy and support from national and international NGOs further strengthened the civic movement in Aceh. Even though this new activism was initially religiously neutral or even secular in its nature, many students from Islamic universities such as the ArRaniry State Islamic University were among the most active advocates of this new energy. Many women activists, including victims of conflict, emerged during this period and were as actively engaged as their male counterparts. While religious conservatism steadily gained support and its advocates became more organised, the religiously neutral and secular activists became more comprehensive in their outlook, realising they could not antagonise traditional Islamic groups and religious convictions while operating in Aceh. Interestingly enough, women were among the leading advocates of this convergence, and to overcome religious conservatism they had to work both with the political establishment and with the existing Islamic institutions utilising religious language and aspirations.

Conflict and violence in Aceh for nearly three decades led to the victimisation of numerous men, women and children, with the latter two suffering the most. As conflicts intensified in the last decade of Suharto's iron grip over Indonesia, Aceh was put under the 'Operasi Darurat Militer' (DOM - Military Emergency Operation). During this period, certain pockets of Aceh underwent great intimidation and brutality with many hundreds of Acehnese killed without this being known by the rest of the citizens of Indonesia. As reformasi erupted and DOM was finally lifted in 1998, the numerous military atrocities in Aceh were unveiled to the public eye. Aceh received sympathy from the across the nation and internationally - which strengthened Acehnese civil society. Initially, while the situation in Indonesia progressed, Aceh suffered even further. The information about military atrocities during the DOM period fueled Acehnese support for independence (merdeka). For the first time ever a large majority of the population in this province would have selected the merdeka option had they been given a chance to hold a referendum, which became the popular demand at the time. To contain the political unrest, thousands of non-organic troops 
were inserted into Aceh, and in May 2003 during the era of President Megawati Sukarnoputri the province was once again put under military emergency law (a while later a civil emergency was imposed), which was only lifted in 2005 after the convulsive disaster of the Tsunami inundation. Consequently, the bloodbath of torture, killings, and sexual abuse of women became a daily reality. The Indonesian military victimised many women during this period, and burnt numerous villages and towns, while gangs of orang tidak dikenal ('unknowns') burnt over one thousand local schools during this emergency era. Although most of the schools were rebuilt and victims were rehabilitated after the signing of the 2005 peace agreement in Helsinki in the aftermath of the Tsunami, the pervasive fear, intimidations, extortions and the severe limitations of movement during that era could not be easily forgotten or forgiven.

In the midst of the high civilian contentions and referendum demands, a group of Aceh women convened in February 2000 the first All Acehnese Women Congress of Duek Pakat Inong Aceh attended by 437 women from across this province. Women activists led by Naimah Hasan walked a fine line, ${ }^{8}$ taking a neutral position between the demands for referendum (inviting independence) or for re-integration with Indonesia. They also had to convince both the military and the rebel leaders of their neutrality and the importance of their Duek Pakat. Several women leaders, for example, had to sneak into the jungle to meet the late GAM military commander Tengku Abdullah Syafi ${ }^{\prime} i$ in his hide-out in order to solicit his blessing for their congress and to request the participation of the GAM female combat wing known as the inong balee (lit. 'female widowers'), even while the military was circling the area in order to capture him dead or alive. ${ }^{9}$ Intimidation, terror and coercion for or against the existing options of plebiscite and re-integration were among the challenges faced by the organisers and participants of this congress. Some participants even walked out during the deliberations accusing the Duek Pakat of having been hijacked by the reintegration camp, while one outsider told a student participant: "you are dead if the congress recommends a referendum." 10 What was interesting about this congress is the fact that women in Aceh were among the first to demand that "the Aceh conflict be resolved through dialogue and nonviolent means." 11 They were also the first to request the quota of 30 percent women representation in politics and decision-making, long before the issue was debated at the national level in Indonesia. The Duek Pakat also publicly registered women's support for the implementation of sharī $a h$ law, requesting a form of Islamic juristic practice friendly toward women. ${ }^{12}$

Praise for this deliberative council of women was great. The late Acehnese historian M. Gade Ismail was quoted by the Jakarta Post: "The most valuable thing to come out of the Duek Pakat ... is that women are showing us men and 
the students how to solve differing points of view in a democratic manner."13 Another person spoke of the Duek Pakat in the context of "Acehnese women map the future." Indeed at the time when the voices of moderation were absent, these women filled the gap. When the Acehnese were polarised between the rival camps of referendum and that of re-integration, women initiated a middle way by concentrating on the process rather than the result. They insisted that whether it be merdeka through referendum, or reaffirmation of Aceh's connection with Jakarta, the issue had to be debated in a non-violent manner. Women's capacity to negotiate their presumed victimhood by turning it into strength, guided the path of their society and country. The voices of women in this Duek Pakat became a turning point, for since then many have followed the example set by these courageous women in their demands for negotiation and for seeking a peaceful means to resolve the Aceh conflict.

Women's demand for compromise to solve the conflict became increasingly adopted in the province, for despite a few failures at the end of the road in 2005 the peace agreement between GAM and Jakarta was achieved through nonviolent means. But their call for women political representation in public life has been a continuing struggle. Even though women have succeeded in putting in place regulations for their 30 percent representation in the political process and decision-making activities at both the national Indonesian and provincial Acehnese levels, such laws have never been properly implemented. Loopholes in the laws and lack of will among the political authorities are some of the obstacles preventing women from achieving due representation in different dimensions of public life. The following example explains both the ambiguity of the law and the absence of good will among the political elites. The Indonesian election law of 2003 requires every political party to register 30 percent women representation in their party leadership structure and on their candidacy list. To meet this requirement the party enlisted female relatives or friends of the party leadership who often had no experience, and registered them on the "shoe number [nomor sepatu]" on their candidacy list. Since the law followed a vertical voting system accumulating all votes onto the first and the next candidates on these lists, very few women received enough votes in Aceh in the 2004 nationwide elections. Similar experiences have occurred across the country.

Though the law has since been improved, the women's struggle continues. The current election law passed in 2009 requires political parties to crisscross one woman for every two male candidates on the candidacy list, but this slight improvement of the status of women in the law from the previous "shoe number" did not increase women's election to the parliament. At the national level, out of the 560 members of the 2014 parliament there are only 79 female representatives, or 14 percent - and this is lower than the 2009 parliament when 103 women, 
or 18 percent, became national law makers. The situation in Aceh is the same: of the 81 parliamentary seats in 2014, women gained 12 places or 14 percent, compared to the 2009 elections when only five women, or seven percent, assumed the parliamentary positions of 69 members. ${ }^{14}$ Numerous reasons contributed to women's inability to gain access to the 'male world arena.' Among the many factors that put barriers on women are the high elections costs and the prevalence of money politics in which women are inexperienced players. The placement of women's candidacy on the zigzag number 3, 6 and 9; the lack of a political network; and the lack of logistical support from the party leadership are other obstacles preventing women from gaining equal representation in this political field. In other words, in spite of improvements in the law, many political parties continue to regard women as only fulfilling regulatory requirements without whose participation their own election registration would be void. This shortsighted political culture remains strong in Aceh and across the country.

\section{Challenges and Cultural Possibilities}

Women have always been active in public life in Aceh. Traditional Acehnese society centered around villages never explicitly talked about gender equity and women's public engagement, yet women were involved in every aspect of village activity. It is true that very few women had assumed the position of village heads, but until as recently as 1995 when the law on local government was enacted the position of the village head was more symbolic. Village activities were run by the most influential members of society, namely the Ulama and enlightened leading individuals, the wealthy and the most generous. A few of these persons were women who were the most influential in their village, including during the elections of village heads..$^{15}$ This was the era when politics, intrigues and hope for financial gains were remote from village experience. Although the 1979 and 1995 laws on village governance do contain a positive statement on the role of women and require a female representative in the village council, yet in practice that very same position actually mitigates the traditional collective voluntarism of influential women in village affairs. Coupled with financial gains for village leadership promised by these laws, collective responsibility slowly subsided in many Acehnese villages. For the same reasons, united female engagement in their village life became minimal. Politics and selfish intrigues have further damaged the situation, and now most village activities and women involvement in community affairs is decided from the top. Ironically, such is the price of modernity and legal reform.

This relapse or regression of the strength of women in village leadership does not mean that women's participation in public life in traditional Acehnese society disappeared completely. The traditional form of income generation should reflect 
a positive reality. The most important rural income production in Aceh is farming and selling produce in the traditional markets. The two are connected for each supports the other. The involvement of women as vendors in markets remains overwhelming, and they continue to control a great number of small and medium size operations. This commercial activity allows women to contribute to their family income and to be financially independent to some extent. Although these informal business actors may not play a very important role in the country's economic growth, since very few of these women could make a decent income, they indeed contribute greatly to the wellbeing of their family and the fair upbringing of children - and thereby to the health and vigor of society. These petty-trader women often possess bargaining power and are very independent. In addition to the market, women in Aceh are also active in agriculture. In this arena women share more than half the work of planting, caring and harvesting of agricultural products (esp. rice and vegetables), thereby controlling their family finances. They often decide either to sell the produce or to retain them for family consumption. Such economic independence is a reflection of their strong character manifested in their overall role as equal partners in both the household and society.

Cooperation between men and women in traditional society has to some extent influenced daily life in urban centers. Medium size enterprises and petty-trade in Aceh's cities and towns still depends on a partnership between men and women. However, the real challenges occur in the areas of modern urban occupations, such as employees in government offices, in political parties, the police force, academic institutions, major local and national companies, international corporations, important social organisations and the Ulama body. All these institutions are important because they control most of the resources, decide policies and shape public opinion. When the 2000 Duek Pakat requested 30 percent female representation in politics and in decision-making bodies, the women participants had in mind all these institutions. Although over recent years they have succeeded in incorporating the 30 percent quota into laws and regulations at both local and national levels, women continue to face great obstacles in putting those laws into practice. Similarly, they have been able to persuade the Ulama Consultative Council (MPU) since 2007 to accommodate female representation in its leadership structure, but again such singular women have not been allowed to play a key role in this important organisation's decision-making. The police force has also been accommodating women, but female officers are still far below quota. Finally, major business enterprises are still beyond women's reach, given that few women are truly large entrepreneurs.

The challenge to implement the 30 percent quota remains a constant exertion and the following two examples reflect this reality. After the 2006 provincial 
elections women in Aceh worked to transform the tiny Women Empowerment Bureau in the provincial government system into the Women Empowerment and Child Protection Body (Badan) with a major profile and sizable budget. They worked hard and negotiated the issue with Aceh's Governor, Vice Governor, members of parliament, and political parties. Although they experienced a number of setbacks along the way, the government and the parliament finally accepted the proposal and transformed the Bureau into the Badan. However, this was not the end of their struggle, for a new challenge of selecting the right person to lead this Body emerged. Since its inauguration in 2008 the Governor has appointed three different women to lead the Badan, and the selection of the second one was regrettable for she had little interest in women empowerment and gender equity. When the then Governor Irwandi Yusuf was questioned about placing the wrong individual to head this institution, sadly his response reflected his indifference to women's concerns: "I cannot resist, she keeps asking." 16 The current leader of the Badan is slightly better, but her political and cultural conservatism, coupled by her attachment to the ruling party prevents her from viewing women issues from a wider and a more comprehensive scope. The above Irwandi episode and the current practice show the nature of political culture in contemporary Aceh, and women's continuing need to struggle in order to gain political rights and their legal share in decision-making.

The second example is more telling of the unproductive environment for women's engagement in public life. The issue emerged in April 2010 when Anisah was sworn in as camat (head of sub-district) in Plimbang in North Aceh. While Anisah was not the only female camat in Aceh, her position became very controversial when the head of the local parliament in that district - Ridwan Muhammad, of Partai Aceh - argued for her removal on the basis that in a province such as Aceh ruled by the sharī ${ }^{`} a h$, a women could not be a legitimate political leader. ${ }^{17}$ His conservative judgment led to heated debates on the role of women in decision-making with on-going media coverage, and many counter arguments expressed both locally and at the national level. ${ }^{18}$ The Governor, who is also of the Partai Aceh, registered his support for Anisah, ${ }^{19}$ invoking Aceh's history when the four Sultanahs had ruled over Aceh for fifty-nine consecutive years with the full support of the Ulama of that era.

Anisah's fate was decided by the enormous support she received from both men and women across the province as well as from community leaders, yet the controversy reveals the growing strength of a deeply embedded conservative political culture being promoted in certain areas of Aceh. The appeal to shari ${ }^{-} a h$ is being used and abused by ill-educated "illiterate" politicians in order to gain political traction, while the silence of major Ulama leaders over this issue of legitimate female political leadership further complicates the situation. These 
debates did indeed lead to some positive outcomes. They have encouraged people to think seriously about this issue, and many have gone beyond their normal capacity and conventional knowledge to learn more about the range of Islamic legal positions on the issue of women leadership.

While arguing for women participation in politics is a difficult undertaking, women could have gained more success in academic institutions such as schools and universities. However, no Acehnese universities have had women Rectors or even candidates running for the office of Rector. There are several female Deans of academic departments, but their number is insignificant. Similarly, a few women have assumed positions as school principals, especially at the high school level, even though the majority of teachers in such schools are women. The lack of women leadership in Aceh's academic institutions may best be explained in relation to both internal factors concerning women, and those of external public reality. Externally, society and academic institutions have not awarded affirmative action any priority, and although women are normally given the same opportunity they don't have any enthusiasm to run for high office. Secondly, since running for important positions involves 'chopping off the heads of other candidates' when garnering supporters and denigrating rival candidates, most women are not prepared for such unhealthy distasteful competition. Internally, a few women who meet the requirements for such positions are prevented from running due to their personal situations including family responsibilities or the attitude of their husbands. Another internal factor placing obstacles on women is the concern that they would not receive proper support even from other women, and therefore it is better not to run. Thus, family pressures and lack of self-confidence are two chief internal factors preventing women from moving forward in this arena. In order for them to climb this ladder they should not be faced with a choice of family or career. Rather, women should receive support in their efforts both to raise family and to advance their career. This undoubtedly requires unfailing assistance and cooperation from their husbands and other family members, for only with their corporation may women progress in both domains. The lesson here is that women's empowerment is not just about educating women - but about enlightening husbands and young men as well.

\section{Contemporary Conditions for or Against Women Empowerment}

In addition to these issues, the following two contemporary conditions may further hinder women's advancement in Aceh. One is the dominant political conservatism widespread in society, and the other is parochial religious fanaticism. The Acehnese government, like the rest of Indonesia, has never been very willing to accommodate gender concerns without effective pressure exerted 
from women and by international bodies like the United Nations. True: the forces acting from within and from without have gradually changed the political discourse in Aceh and throughout Indonesia, leading to the reform of laws and public regulations. Nevertheless, the implementation of those legal requirements continues to be problematic, even though government rhetoric on gender has often been accommodating. The situation is even less constructive in Aceh.

Although Aceh has a long history of women leadership and the general positive attitude towards women social involvement, their experience in politics is not very encouraging. Since the 2009 elections of GAM leaders through their Partai Aceh to govern the province, women met a more conservative political environment. The controversy over a female camat described above reflects the recent spread of political conservatism. Even Irwandi, who supported the legitimacy of the female camat, is conservative on many other gender issues. The reason for his selection of the Head of the Women Empowerment Body mentioned above, the budget he assigned for gender concerns, and his views on certain cultural-religious practices such as polygamy are just a few examples of his conservatism. The current Governor Zaini Abdullah is not very different either. He is not known for supporting women's agenda and his silent attitude is overtaken by his more flamboyant Vice Governor famous for his love of women and enthusiasm for polygamous marriage..$^{20}$ The latter is also known for his religious conservatism. As one activist commented: "We cannot confirm his support for women since the issue of equality is the lowest of his agenda. Unfortunately, neither he nor the Governor has promoted a constructive policy for women after more than two years in the office." ${ }^{21}$ The local parliaments both at the provincial and district levels were then controlled by the Partai Aceh, whose many members were quite insensitive toward female issues. ${ }^{22}$ The current parliament selected in 2014 has reduced the Partai Aceh membership, yet the provincial government's gender concerns remain lower in priority. The Partai Aceh not only tolerates but promotes polygamy, and many of its leaders, including the current Vice Governor, are polygamous husbands. ${ }^{23}$ In fact, since their rise to power, polygamy has become a statement of status among political elites. Conservative political culture is also reflected in the policy and programs of the provincial government, and therefore "gender mainstreaming efforts are not moving anywhere. ${ }^{.24}$ In short, the political culture and religious conservatism promoted by the Partai Aceh, and supported by certain religious establishment figures, have created a low intellectual and social atmosphere that is unhealthy for future women equity projects. ${ }^{25}$

In addition to parochial political conservatism, religious fanaticism is also on the rise in this province. While Aceh has always been a very devout Muslim region and the Acehnese are proud of their Islamic roots ${ }^{26}$ many are quite concerned with 
the ways Islam is now being applied. Women do support the implementation of the shari ${ }^{\top} a h,{ }^{27}$ as they clearly expressed during the Duek Pakat, because they believe strongly in the Islamic principles of justice and equity. "Shari' ah is about justice and the protection of the weak, but the version of the shari $a h$ being implemented in Aceh is about punishment and exposing the wrong doing of others." ${ }^{28}$ The problem with the Acehnese version of the shari' ah is that "everyone claims it is God's law while in reality it is the interpretation of God's law by the Ulama and politicians. Our inability to distinguish between human interpretations and divine injunctions is a serious matter." ${ }^{29}$ Another criticism regarding the application of shari ${ }^{\top} a h$ law has to do with the target of legal enforcement. The critics observe that the shari' ah has only punished women and the weak, while the politicians and the powerful have not been touched by it. ${ }^{30}$

In spite of all these criticisms, many women continue to expect that the shari ${ }^{-} a h$ can truly promote the spirit of justice and equality ${ }^{31}$ - and thus the problem is not with the shari' ${ }^{\prime} a h$ as such, but with the manner it is being interpreted and applied. Other women feel that the sharī ah can never be just toward women, but they have no choice except to work within the existing legal framework. Despite the differences of opinion, these two groups of women often work together in order to accomplish common objectives. In addition, there are others who always view the sharí $a h$ or its implementation very positively, and these represent the most conservative among Acehnese women. According to them, the problem is not with "God's law and its application" but with the people who are not following divine commands. ${ }^{32}$ Aligned with each of these three main orientations one finds men who share their respective views, and thus the discourse on shari ${ }^{\top} a h$ in Aceh is dominated by these three differing views, with the first two often found supporting each other.

These debates among lay women and men are also reflected in discourse among the Ulama. While all of the Ulama in Aceh unequivocally support the shari ${ }^{\top} a h$ and have worked hard to get it adopted by the government, it is the Acehnese traditional Ulama heading the dayahs (religious boarding schools) represented by the MPU who are truly the core of Acehnese religious authority. They are generally open to criticisms concerning the implementation of the shari ${ }^{\top} a h$ as long as these views are expressed in a proper venue and in a dignified manner. As a matter of practical distinction, I may refer to them as the sarung Ulama [i.e. who wear traditional clothing]. In addition to this traditional or salafi religious establishment, there are university Ulama who are largely professors and graduates of Ar-Raniry Islamic University, being the most open to pluralist views and social-religious criticisms. These 'white collar' Ulama are also well represented in the MPU. The two groups share a great deal of commonalities, but are not always in agreement. The third type is the most conservative group 
and is a new comer in Aceh. This group may be identified as the jubbah religious authority [wearing the white Arab-style shirt or jubbah], and comprises several groups of outside origin: Hizbu t-Tahrir, ${ }^{33}$ Jama ah Tabligh, ${ }^{34}$ Wahhabis,${ }^{35}$ as well as several national groups that all arrived in Aceh recently to assist during the 2004 Tsunami, and have grown roots in the province. The jubbah Ulama are very active in promoting their views and, despite being outside imports, they are gaining ground in Aceh. The most conservative women group mentioned above belongs to this new jubbah religious establishment.

Although all of these Ulama groups and their women supporters share the same enthusiasm for the sharī $a h$, the Ar-Raniry Ulama are more understanding of women's predicament in the context of the unintended abuses of shari'ah. The sarung Ulama are also listening to criticisms and complaints, but they are more careful and limited in their accommodations and responses. In contrast, the jubbah leaders see nothing wrong in the shari ${ }^{\prime} a h$ implementation, suggesting that problems have arisen due to the lack of positive responses from the public and therefore, more severe forced implementation is necessary. Although the sarung Ulama share very little in common with the jubbah group regarding Islamic viewpoints, when it comes to shari ${ }^{\top}$ ah discourse the sarung Ulama are in alignment with this ultra-conservative group. A prominent leader of MPU Teungku Ismail Yacob stated about the jubbah leaders:

Even though the [dayah] Ulama disagree with the ways in which they express their views, they help promote greater support for the sharī $a h$. Their opinions on certain aspects of Islam in the manners of just halal and haram are problematic because Islamic norms consist of more than halal and haram options. ${ }^{36}$

Since the salafi Ulama rarely express their opinions on controversial issues in public, the general masses are left vulnerable to the conservative views of the jubbah groups, or those of the Ar-Raniry scholars. When asked the reasons for their silence, the dayah Ulama's typical response: "these are minor issues." One wonders what are their major concerns? Proselytising is certainly one ${ }^{37}$ Another explanation for their silence is that the Ulama generally dislike to contradict one another in public, and therefore when they disagree on issues they discuss them behind closed doors. Solidarity and consensus is a chief characteristic of Ulama culture in Aceh, as elsewhere in Muslim societies. However, the new more radical jubbah Ulama do not appear to exhibit this characteristic, and therefore they are outside the mainstream. The real concern is that such radical well-organised groups may assume the lead in providing public guidance, which in turn puts them on better terms with the masses.

Too much attention to obstacles may distort reality. Among the conditions 
that provide hope for women empowerment are women factors. Two of the three groups of women described above are active members of society and are well aware of the obstacles which hinder gender equity. These women groups work in different arenas to improve their own condition and those of their families and society. Similarly, the conservative group is also providing services, but its activity falls outside the purview of this study. Two examples may explain the nature of activism by women groups in promoting gender empowerment. One is the effort by the dayah women who seek to shine within their cultural limits. Women presently consist of about $1.5-2$ percent of the dayah leadership in Aceh, for there are only ten to fifteen women among the seven hundred dayah leaders. Therefore, dayah culture is overwhelmingly male in nature. ${ }^{38}$

However, a few women who are leading dayahs work systematically to break barriers and to act within the constraints of the dominant dayah environment. Their mission is significant on a number of grounds. First, internally they are reclaiming the role and the position of women in the predominantly male world of the dayah and Ulama, highlighting the veritable Islamic position on equal rights and shared responsibilities between men and women in seeking and disseminating knowledge. Second, they are also providing religious leadership in the community which is otherwise dominated by male Ulama - demonstrating that females can also exercise Islamic intellectual and spiritual authority. Thirdly, they offer themselves as religious role models not only for young women but for young men as well, since their students in the dayahs are both male and female. Lastly, dayah women leaders and teachers may enrich debates on the role of women in public life not only for the consumption of the general public but, more especially, for the enlightenment of the dayah community. Ummi Rahimun, one of the dayah leaders in Aceh Besar, expresses her view that "the involvement of women in politics is necessary since women like their male counterparts are given the responsibility to bring benevolence (rahmah) and goodness (kebaikan) to others." She contends that many Hadiths (narrated traditions from the Prophet) support women's social engagement, and that dissenting views are in contradiction with "the spirit of Islam and Prophetic practice." 39 This type of discourse by a noted female Ulama such as Rahimun is sorely needed in the social and religious context of contemporary Aceh.

The second group of women who are laying the groundwork for women empowerment are the general social activists. As mentioned earlier, they are of two types: the religious and the liberal. ${ }^{40}$ These two groups view the role of Islam in public life differently, yet they share the view about the need for active engagement of women in society. They argue that this cannot be achieved without hard work by women themselves. Therefore, some concentrate on improving the legal foundations for the empowerment of women, ${ }^{41}$ while others provide 
assistance to inexperienced female members of parliament and policy makers in order to help them improve their capacity and be aware of gender concerns. ${ }^{42}$ Furthermore, they represent women assisting other females and their families to improve their quality of life, and by so doing they hope to make these women aware of their rights and responsibilities in their respective surroundings. Finally, there remains a large number of women who constantly try to improve their own qualifications through both formal and non-formal education in order to become better members of family and society and better their material conditions, so that they may compete for political appointment and important public offices. All of these women are indeed true agents of change in contemporary Aceh.

In conclusion: The present study demonstrates that peace building forms an Islamic core value manifested in the inner provision of human capacity (fitrah), in human relations with the divine, in their horizontal connections as community members, and in their treatment of nature. Women as part of the human family are endowed with rights and responsibilities to enjoy and fulfill their earthly obligation of maintaining and promoting peace. However in reality this remains a luxury for most women who continue to struggle to overcome difficult conservative religious, cultural and political battles in order to claim the very provisions bestowed upon them by God al-Sălam. Understanding these Islamic core values provides Acehnese women genuine hope to pursue their striving for their Islamic endowment of equality and justice.

\section{Policy Recommendations}

Our study on the role of Acehnese women in advocating peace and justice invites reflection on broader efforts for women equity across communities and cultures. Government ministries, planners, and civic actors must heed and apply the following insights.

- Women empowerment and social justice are essential Islamic principles that should be embraced by all Muslim communities and cultures for they are important milestones for reviving civilisational Islam.

- Women empowerment is not only about educating women about their rights and responsibilities, but more significantly about enlightening husbands and young men in society to uphold essential principles.

- Women empowerment always works against cultural conservatism and religious fanaticism, since these two often impose a low intellectual and social atmosphere dangerous for both women agenda and civilisational renewal.

- Muslim women including the Acehnese sincerely believe and continue to expect that the sharī ah can truly promote the spirit of justice and equality. 


\section{Notes}

* Asna Husin teaches Philosophy of Education and Islamic Civilisation at the Ar-Raniry State Islamic University Darussalam in Banda Aceh, Indonesia. She gained a Master's Degree in Middle Eastern Studies from Harvard University (1992) and her Doctorate in Religious Studies from Columbia University (1998). Dr. Husin was an Associate Fellow at the Center for the Study of Human Rights at Columbia University (1998) and directed the Women's Program at the World Conference on Religion and Peace (WCRP) in New York from 1998 - 2000. In 2000 she established in Banda Aceh the Peace Education Program (PPD) as an independent affiliate of the NGO Nonviolence International (NI) when she worked closely with the government of Aceh and Ulama institutions. Dr. Husin participates in academic conferences worldwide on Islamic peace, gender equity, Ulama institutions, and civilisational heritage.

1. Those unfamiliar with the 'causes of revelation' of the Qur'ān (the exegetical genre known as asbāb al-nuzül) should be mindful that among the many occasions of Qur'ānic revelation were events provoking answers and responses to requests by the Muslim community of the time - including prominent women. The complaints and veiled protests by the Prophet's wife Umm Salamah fall within this category.

2. See Wahbah al-Zuhaylī, Al-Tafsìr al-Munìr fi l-Aqīdah wa al-Sharīah wa l-Manhaj (Beirut: Dār al-Fikr al-Mu'āṣir, 1411/1991), vol. 22, 17.

3. See narratives of courageous women in Islam recounted in Wiebke Walther, Women in Islam: From Medieval to Modern Times (Princeton: Markus Wiener Publishers, 1995).

4. For the semantic scope of these terms see Karim Douglas Crow, "The Concept of Peace-Security (Salm) in Islam: Uncovering the Basis of Islamic Peace," in War and Peace in Islam: The Uses and Abuses of Jihad, ed. HRH Prince Ghazi bin Muhammad et. al. (Cambridge UK: The Islamic Text Society, 2013), 250-268.

5. Cited by Ibn Hishām in his al-Sirah al-Nabawìyah on an unknown authority; also cited by al-Bukhāri, șạịh, vol. IV, 136.

6. For further information about these women refer to A. Hasjmy, 59 Tahun Aceh Merdeka di Bawah Pemerintahan Ratu (Jakarta: Bulan Bintang, 1977); Banu A. L. Khan, "The Jewel Affair: The Sultana, Her Orangkaya, and the Dutch Foreign Envoys," paper presented at the Conference on Aceh and Indian Ocean Studies, organised by the Rehabilitation and Recontruction Agency of Aceh (BRR) and the Asia Research Institute, Singapore (Banda Aceh, 24-27 ${ }^{\text {th }}$ February 2007); Iljas Sutan Pamenan, Rentjong Atjeh di Tangan Wanita: Zaman Pemerintahan Radja Putri Atjeh, 1641-1699 (Jakarta: 1959, self-published); also refer to the prominent Acehnese women during the wars against the Dutch in H.C. Zentgraaff, Atjeh, trans. Aboe Bakar as Aceh (Jakarta: Penerbit Beuna, 1983), 77-147.

7. For a comprehensive description of the Indonesian new revolution, refer to Kevin O'Rourke, Reformasi: The Struggle for Power in Post-Suharto Indonesia (Crows Nest, NSW: Allen \& Unwin, 2002).

8. For a brief biography of Hasan refer to Asna Husin, "An Exploration of Three Contemporary Acehnese Peace Leaders," in Women and Peace in the Islamic World: Gender, Agency and Influence, eds. Yasmin Saikia and Chad Haines (London and New York: I.B. Tauris, 2015), 136-168. 
9. Tengku Abdullah Syafi'i was killed by the Indonesian military while still in hiding in January 2002.

10. The Jakarta Post (February 27, 2000).

11. Interview with Naimah Hasan (December 2013).

12. For an excellent study on the shari ' $a h$ as a potential tool for social transformation in contemporary Aceh, consult R. Michael Feener, Shari'a and Social Engineering: The Implementation of Islamic Law in Contemporary Aceh, Indonesia (Oxford: Oxford University Press, 2014).

13. The Jakarta Post (February 27, 2000).

14. For detailed analysis refer to "Sulitnya Wanita ke Parlemen" in local daily Serambi Indonesia, 28 April, 2014.

15. As a young girl I observed that my female religious teacher, my mother and a few other local ladies were consulted about every move of our village. Nothing could happen in the village without their support, and these great women always acted in the best interests of their village and community, and were among the wisest and most generous leaders. These ladies also worked together as a group in support of their male counterparts and the village head.

16. His response in Acehnese: "han ek kudeungoe dingeng-ngen sabee", was reported by the former Dean of the Law School at Syiah Kuala University, who was an advisor to the Governor.

17. Rejection of women camats in other parts of Indonesia occurred in 2001 when the selection of five female camats by the Bupati of Tasikmalaya was refused by the community on religious grounds.

18. For a good overview of the debates refer to the article in Modus Aceh (November 24, 2010) and provincial daily Serambi Indonesia (October 2010).

19. See "Berdalil Syariat, Irwandi Tolak Copot Camat Perempuan," The Globe Journal (October 8, 2010). Among the national newspapers discussing this case, see "Opposition to Woman's Leadership of District Wanes," The Jakarta Post (October 12, 2010).

20. These two Partai Aceh members were elected as Governor and Vice Governor of Aceh on 9 April 2012.

21. Interview with Syarifah Rahmatillah of MISPI (August 2014).

22. Interview with T. Husein Banta (14 October, 2010).

23. No serious study has been made on the practice of polygamy among PA leaders or among the contemporary Acehnese, but judges at the religious courts and female lawyers who defend divorce cases clearly suggest that polygamy is on the rise in Aceh, and GAM leaders are among the faithful practitioners of polygamy.

24. Statement by a former member of parliament during the discussion on gender sensitive budgeting (9 December, 2013).

25. One example of this low culture occurred on 10 March, 2015 when the Rector of Ar-Raniry Islamic University met with a group of 30 women activists under the program "Meet the Rector." This professor spent the first half hour of his twohour speaking session dwelling on the importance of polygamy which generated protests from some members of the audience.

26. Aceh is credited for the historical spread of Islam in the Archipelago and for the development of Islamic intellectual scholarship throughout Indonesia and the entire Malay speaking region in South East Asia. 
27. For an excellent concise discussion of the $\operatorname{sharì~}^{-} a h$, consult Mohammad Hashim Kamali, Shari ah Law: An Introduction (Oxford, UK: Oneworld Publications, 2008); also Wael E. Hallaq, An Introduction to Islamic Law (Cambridge: Cambridge University Press, 2009).

28. Interview with Nurjannah Ismail (March 2010).

29. Interview with Fuad Mardhatillah (September 2010).

30. For a balance of views on the application of the sharì ah in Aceh see Husin, "Women and Shari'ah Law".

31. For details see Feener, Shari' $a$ and Social Engineering.

32. Global groups such as Hizbut Tahrir Indonesia (HTI) fall under this category. It is one of the most active groups advocating the implementation of Islamic law through its utopian idea of khiläfah (Islamic caliphate).

33. For an Introduction to Hizbut Tahrir consult Houriya Ahmed and Hannah Stuart, "Hizb ut-Tahrir Ideology and Strategy," a publication of the Center for Social Cohesion (London, UK, 2009), at http://henryjacksonsociety.org/wp-content/ uploads/2013/01/HIZB.pdf (accessed in August 2015).

34. For a brief exposition of the Tablighi, see "Jamaah Tabligh di Tengah Kritisi Positif dan Negatif," in Era Muslim: Media Muslim Rujukan at http://www. eramuslim.com/umum/jamaah-tabligh-di-tengah-kritisi-positif-dan-negatif.htm (retrieved September 2014).

35. Wahhabism had arrived in Aceh prior to the Tsunami largely through the Acehnese graduates of Saudi universities who promoted the puritanical type of Islam upon their return to Aceh. Some of them have even established dayahs in some areas of Aceh. However, in spite of their initial puritanical views, the preTsunami Wahhabi leaders worked within the Ulama system by making necessary adjustments and cultural changes. The post-Tsunami Wahhabism arrived in Aceh with Gulf money supported by Indonesian promoters predominantly from Java. Unlike the Acehnese Wahhabis, the new comers are outside the mainstream of Aceh's Ulama leadership and culture.

36. Interview with Tengku Ismail Yacob (November, 2010).

37. In early 2010 the Ulama were speaking against conversion of Acehnese to Christianity by some NGO workers assisting in Aceh after the Tsunami.

38. For the role of women in Aceh's dayahs, see Asna Husin, "Leadership and Authority: Women Leading Dayah in Aceh," in Gender and Power in Indonesian Islam: Leaders, Feminists, Sufis and Pesantren selves, eds. Bianca J. Smith \& Mark Woodward (London: Routledge, 2014), 49-65.

39. Rahimun referred to the widely reported recent controversy and debates over women's political leadership in Aceh in her response to the right of a woman to be a sub-district head (camat) and other political appointments (see Husin, "Authority and Leadership").

40. The term 'liberal' does not imply their being irreligious, since with respect to personal devotions they may be as devout as the more conservative religious.

41. Jaringan Perempuan untuk Kebijakan (Women Network for Policy Improvement) is one of the significant groups created by women to negotiate legal and policy issues.

42. Mitra Sejati Perempuan Indonenesia (The True Partnership of Indonesian Women) and Balai Syura Ureng Inong Aceh (The Consultative Council of Acehnese Women) are two major women organisations focusing on capacity-building of female policy makers. 